УДК 346.1

DOI https://doi.org/10.32849/2663-5313.2019.7.6

\title{
Олена Гониаренко,
}

канд. юрид. наук, дочент, старший науковий співробітник відділу правового забезпечення ринкової економіки

Науково-дослідного інституту приватного права і підприємничтва імені академіка Ф. Г. Бурчака Начіональної академї правових наук України

\section{КОРПОРАТИВНИЙ АКТ ЯК ЗАСІБ САМОРЕГУЛЮВАННЯ ГОСПОДАРСЬКОЇ ДІЯЛЬНОСТІ}

Досліджено особливості корпоративного акта як засобу саморегулювання господарської діяльності. Корпоративний акт визначає, формалізує «правила гри» для учасників та членів корпоративної спільноти (корпорачї), спрямований на деталізацію упорядкування відносин. Встановлено, що окремі види корпоративних актів є елементами у системі «м'якого права», які створюються та формуються суб'єктами господарювання та їх об'єднаннями (трансначіональними компаніями, саморегулівними організаціями та окремими суб'єктами господарювання). До засобів «м'якого» права відносять публічні документи, акти спільного регулювання та приватного саморегулювання, які носять здебільшого рекомендаційний характер або стають обов'язковими унаслідок домовленостей між сторонами або одностороннього волевиявлення. Визначено, що корпоративний акт як засіб саморегулювання господарської діяльності - ие документ, незалежно від назви, форми, структури та змісту, який самостійно приймається, ухвалюється певною корпоративною спільнотою, організацією (господарським товариством, господарським об'єднанням, саморегулівною організачією) з питань упорядкування певної сфери, галузі, виду господарської діяльності або внутрішньогосподарської діяльності, у межах чинного законодавства та міжнародних договорів. Корпоративні акти є більш гнучкими порівняно із законодавчими нормами, мають відмінний механізм прийняття, володіють ознакою нормативності. Корпораиії можуть приймати індивідуальні акти, які не містять норм, ає результатом функиіонування їхніх органів. Корпоративні акти можуть бути певною альтернативою державному нормативному регулюванню (у разі дозволу) або ж бути додатковим регулюванням до основного. Корпоративні акти можуть мати транскордонний, трансначіональний характер, виходячи за межі певної держави. Слід доповнити статтю 7 ГК України частиною 2 такого змісту: «Відносини у сфері господарювання регулюються нормативними актами суб'єктів господарювання, саморегулівних організаиій. До таких актів можуть бути віднесені: приниипи корпоративного управління, етичні кодекси, регламенти, добровільні угоди, стандарти, кодекси усталеної практики. Перелік не є вичерпним та не залежить від назви нормативного акта. Суб'єкти господарювання, саморегулівні організаиї̈ можуть приймати нормативні акти у межах, визначених законодавством України та міжнародними договорами».

Ключові слова: саморегулювання, саморегулювання господарської діяльності, саморегулівні організації, корпоративна спільнота, корпоративний акт, засіб саморегулювання, «м'яке» право.

Постановка проблеми. Дослідження питання саморегулювання господарської діяльності не буде повним без вивчення особливої природи корпоративного акта як засобу саморегулювання. Корпоративні акти відносять до нормативних інструментів саморегулювання. Коло їх різновидів доволі широке: правила етичної поведінки представників корпорацій, кодекси корпоративної етики на рівні як окремої юридичної особи, так і певної асоціації, до якої входять суб'єкти господарювання, статут, «добра» практика тощо.

Аналіз останніх досліджень і публікацій. Проблематику саморегулювання госпо- дарської діяльності в Україні досліджували такі вчені: О. Бакалінська, О. Беляневич, В. Кочин, В. Махінчук, В. Полюхович. Особливість корпоративного акту вивчали: В. Антошкіна, О. Тичкова, М. Томашевська, П. Пальчук та інші. Однак в українській науці недостатньо визначені питання корпоративного акта через призму саморегулювання.

Метою статті є визначення корпоративного акта як засобу саморегулювання господарської діяльності.

Виклад основного матеріалу. Говорячи про корпоративні акти, слід зазначити, що 
низка учених відносить їх до джерел «м'якого права». Так, А. Петер відносить право, яке сформульоване приватними (в основному економічними) організаціями до м'якоправових інструментів. Найбільш характерними суб'єктами (спільного) регулювання, що функціонують в Європі, є транснаціональні компанії і торгово-промислові асоціації. Ці приватні (комерційні) актори беруть все більшу участь в «автономіі» саморегулювання [1]. Тому багато саморегулівних засобів («self-regulation tool») відображені у документах урядових та неурядових організацій, які функціонують у бізнес-середовищі. Прикладом цього може слугувати діяльність Міжнародної торгової палати, яка $є$ універсальним майданчиком для кодифікації звичаєвих норм та розробки документів, які $\epsilon$ саморегулівними. Система «м'якого» права доволі складна та може бути розподілена на кілька рівнів - від універсального, регіонального до локального.

В узагальненому вигляді можна говорити про транснаціональну систему «м'якого права», до якої і відносять доробок Міжнародної Торгової Палати, регіональну та локальну (акти окремих суб’єктів господарювання та їхніх саморегулівних організацій). Тому і нормативні акти на рівні таких організацій у різних державах будуть мати свою специфіку.

Ланкою між суто «публічними м'якими» актами та «саморегулівними м'якими» актами $€ \ll$ м'які акти співрегулювання». Фактично сьогодні вони набувають найбільш комплексного характеру та задовольняють інтереси як органів публічної влади, так і представників приватного сектора. А. Петерс наводить приклади роздержавлення м'якого права - появи змішаних приватно-державних актів, які іноді називають «гібридними» або «багатосторонніми» діями або спільним правовим регулюванням (co-regulation). Наприклад, соціальний діалог, у рамках якого ініціатива з внесення законопроектів надається соціальним партнерам (представникам роботодавців і працівників). Вони вправі вступати в добровільні угоди, які надалі приймаються Радою ву формі Директив [1] М'яко-правові засоби допомагають заповнити прогалини нормативного регулювання

Водночас слід зазначити, щодо до засобів «м'якого» права відносять і суто «публічні» документи, зокрема рекомендації Сврокомісії, інтерпретаційні інструкційні документи тощо. Отже, до засобів «м'якого» права відносять публічні документи, акти спільного регулювання та приватного саморегулювання, які мають здебільшого рекомендаційний характер або стають обов'язковими унаслідок домовленостей між сторонами або одностороннього волевиявлення. Наперед імперативної сили вони не мають, однак можуть перетворюватися із норм «м'якого права» на норми «твердого» права (ставати обов'язковими).

Корпоративні акти є елементом у системі «м'якого права». Однак на відміну від інших «публічних м'яких», «м'яких актів співрегулювання» вони мають свою специфіку, оскільки створюються та формуються недержавними акторами (транснаціональними компаніями, торговими асоціаціями, саморегулівними організаціями та окремими суб'єктами господарювання). Водночас статут, засновницький договір суб'єкта господарювання є корпоративними актами, які складно віднести до «м'якого» права, адже їх створення та в окремих випадках реєстрація $є$ обов'язковою імперативною вимогою законодавства. На думку О. Бакалінської, «особливістю корпоративних актів саморегулювання є те, що вони містять самозобов'язання осіб щодо виконання правил і принципів корпорації, закріплюють спільну позицію учасників, передбачають добровільність виконання приписів та відповідальність за їх виконання. До корпоративних актів саморегулювання відносять кодекси корпоративної етики, правила етичної поведінки представників корпорацій, а також акти про нерозголошення корпоративних таємниць та ноухау» [2, с. 246]. Корпоративні акти є засобом саморегулювання господарської діяльності [3, c. 69].

У науковій літературі зазначається, що корпоративні акти є нормами локальної правотворчості [4, с. 160; 5, с. 139], мають нормативну природу [6, с. 13], локальний характер [7, с. 310]; це форма самоорганізації корпорацією своїх внутрішньоорганізаційних відносин [4, с. 159]; це виражена назовні форма рішення засновників або органу управління юридичної особи, що містить певне правило поведінки суб'єктів корпоративних відносин [8, с. 24]; вони спрямовані на регулювання внутрішніх корпоративних відносин, мают більш зручну форму викладу змісту, легший спосіб внесення коригувань і контролю за виконанням, видавники мають більше можливостей порівняно з іншими нормотворцями [4, с. 160]; є самостійним джерелом права, яке встановлюється шляхом здійснення прямого правотворення колективними приватно-правовими суб'єктами в рамках реалізації наданого їм законодавством права, що є складником їхної правосуб'єктності [7, с. 310]; це документ встановленої форми, виданий від імені юридичної особи їі компетентним органом згідно з встановленою 
процедурою 3 метою регулювання відносин, що складаються у процесі регулювання діяльності цієї юридичної особи, містить обов'язкові для виконання правила та встановлює, змінює та припиняє правовідносини [9, с. 120$]$.

Усі вказані характеристики доволі урізноманітнюють характеристику корпоративних актів та показують дискусію щодо правової природи, механізму прийняття. Тому у межах роботи важливо з'ясувати, які ознаки корпоративного акта характеризують його як засіб саморегулювання. Корпоративні акти є більш гнучкими порівняно із законодавчими нормами, мають відмінний механізм прийняття, володіють ознакою нормативності. Корпорації можуть приймати індивідуальні акти, які не містять норм, а є результатом функціонування iii органів, зокрема правозастосовної діяльності (порядок доступу до експлуатації певного обладнання, користування базами даних). Тому корпоративні акти у широкому сенсі можна класифікувати, виходячи з їхньої двоякої природи, на: нормативні та індивідуальні.

Ця стаття присвячена саме корпоративним актам, які включають нормативний зміст, оскільки вони є найвищою формою саморегулювання. У підгрунтя корпоративного акта як формалізованого вияву закладена корпоративна норма, яка є «цеглинкою» цього документа.

Корпоративний акт визначає, формалізує «правила гри» для учасників та членів корпоративної спільноти (корпорації), спрямований на деталізацію упорядкування відносин між суб'єктами створення, погодження. Такі корпоративні акти можуть мати різну назву, структуру, зміст, включати санкції за їх порушення, альтернативні методи врегулювання спорів.

Корпоративні акти можуть бути певною альтернативою державному нормативному регулюванню (у разі дозволу) або ж бути додатковим регулюванням до основного. Корпоративні акти водночас не суперечать чинному законодавству, незважаючи на те, що багато положень приймається за власним розсудом членів організації, виходячи 3 їх бачення та перспектив.

Процедура прийняття корпоративних актів залежно від сфери, галузі, виду господарської діяльності може визначатися, узгоджуватися органами державної влади (спільна позиція) або ж безпосередньо самою корпоративною спільнотою (корпорацією), процедура ж виконання переважно добровільна, «м'яка» (свідомого саморегулювання), однак за винятком делегованого саморегулювання.
Положення корпоративних актів не поширюються на третіх осіб. Юридичну силу корпоративні акти набувають через їх санкціонування державою шляхом реєстрації або затвердження (наприклад, засновницьких документів акціонерного товариства) [4, с. 159], водночас М. Томашевська вказуе ще й на легітимацію корпоративних актів [9, с. 49] в аспекті відповідності положень корпоративного акта вимогам закону та верховенству права. Зокрема, органи державної влади здійснюють державну реєстрацію корпоративних актів (статут), внесення інформації про них, змін тощо до офіційних реєстрів (положення про філії, представництва). Корпоративні акти суб'єкта господарювання, їх види та зміст можуть прийматися на основі правового припису уповноважуючого (дозвільного) характеру, який встановлюється на рівні законів та, відповідно, врегульовує (дозволяє упорядковувати) питання самостійного визначення окремих аспектів корпоративних відносин (наприклад, правила біржової торгівлі). Крім того, органами державної влади можуть надаватися певні зразки корпоративних актів, наприклад типових або примірних (модельних) статутів, які суб'єкт господарювання має імплементувати у свою діяльність.

Доволі часто у працях учених спостерігаємо ототожнення локальної та корпоративної правотворчості. Низка дослідників також вказує на проблематику вирізнення локальних і корпоративних норм та актів [10, с. 86], М. Томашевська наголошує на неможливості їх ототожнення 3 причини належності до різних правових доктрин [9, с. 48], О. Тичкова вказує, що корпоративні норми - це ті, що регулюють корпоративні відносини (причому на різних рівнях - на загальному і локальному), а локальні діють в обмеженому колі осіб [11, с. 51]. Водночас проблема ускладнюється наявністю транснаціональних організацій, які також мають свої корпоративні акти і які набувають транснаціонального характеру. В. Антошкіна зазначає, що «розвиток транснаціональних стосунків, поширення форм і видів цивільних відносин обумовлює перехід від державно-правового регулювання до саморегуляції, до приватноправового регулювання через вироблення індивідуальних, внутрішніх, локальних актів та правочинів» [4, с. 160].

Вважаємо, що локальне регулювання не слід ототожнювати із корпоративним регулюванням, а локальний акт - із корпоративним актом. Локальність - це прив'язка до певного територіального рівня регулювання, тоді як корпоративний акт може мати транснаціональний характер. Водночас О. Тичкова 
зазначає: «Локальне регулювання як форма саморегуляції - це регулювання, здійснюване власними силами і власними засобами корпоративними механізмами, на наданих законом підставах, у межах повноважень/ компетенції органів корпорацій через різні організаційно-правові форми безпосередньої і опосередкованої, прямої і непрямої участі учасників в управлінні» [6, с. 9]. В. Форманюк підтверджує: «Можливість ліквідації правових прогалин локальними нормативно-правовими актами обумовлена вже самим фактом визнання локального регулювання самостійним видом нормотворчості та наданням суб'єктам права визначати зміст зазначених актів» [12, с. 188]. Тому локальні акти - це не тільки корпоративні акти, а й акти органів місцевого самоврядування Звичайно, як слушно зазначає М. Руденко, «локальне регулювання внутрішньогосподарських відносин за своєю сутністю є однією з форм саморегулювання» [13, с. 178-179], «€ одним із проявів саморегулювання на мікрорівні» [13, с. 179]. Однак рівні саморегулювання суб'єктів господарювання можуть бути різними. Тому локальне і корпоративне регулювання має більшість спільних ознак, оскільки належать до недержавного регулювання та інтерпретуються за різними критеріями: суб'єктного складу та ступеня регулювання. І. Кучеренко щодо юридичних осіб приватного права зазначає: «Вони діють на засадах саморегулювання, а їх правовий статус регулюється правовими нормами, які мають загально дозвільний характер, і державою (територіальна громада не відповідає за їх зобов'язаннями [14, с. 15-16]. На засадах саморегулювання діють не тільки юридичні особи приватного права - усі юридичні особи мають більший чи менший ступінь саморегулювання.

Локальний, який не виходить за певні межі; місцевий [15, с. 542]. Водночас корпоративний акт може мати ознаку локальності. Корпоративний акт вказує на суб'єкта походження, від кого він виходить. У буквальному тлумаченні - від корпорації, бо корпоративний. А корпорації можуть бути і транснаціональними. Корпоративні норми можуть бути інтернаціональним правовим явищем [16, с. 136], транснаціональні компанії та міжнародні професійні об'єднання почали формувати власну міжнаціональну культуру [16, с. 136]. Слід додати, що мета діяльності корпорації визначається її власним баченням, що часом не збігається з нормами національного права.

Корпоративні акти не є суто локальними актами у територіальному аспекті. Корпоративні акти можуть мати транскордон- ний, транснаціональний характер, виходячи за межі певної держави, особливо якщо це стосується саморегулівних організацій, які відкривають свої представництва в інших державах. Тобто локальність відбиває характеристику більше внутрішньої координації, упорядкування діяльності між самими суб'єктами господарювання або суб'єктом господарювання у межах своєї компетенції, що може здійснюватися як у межах певної держави, тобто мати національний характер, так і виходити за іï межі. Багато в чому це залежить від характеристики самої юридичної особи, наявності іноземного елемента. Зазначимо, що локальність корпоративних актів притаманна у разі їх створення окремим суб'єктам господарювання або саморегулівним організаціям як особливим формам об'єднань суб'єктів господарювання. Однак саморегулівні організації можуть створюватися на різних рівнях i, відповідно, формувати такого ж рівня корпоративні акти. I. Кириленко зазначає «субординаційний аспект, що характеризує процес локальної нормотворчості як такий, що походить від процесу правотворчості законодавчого та підзаконного загальнодержавного рівня, оскільки результати законодавчої та підзаконної загальнодержавної діяльності визначатимуть процес і зміст локальної нормотворчості, результати якої мають відповідати положенням актів вищої юридичної сили та прийматися на виконання їх положень» [17, с. 28]. Корпоративні акти можуть мати локальний характер, оскільки створюються, перш за все, суб'єктами господарювання та їх об'єднаннями у межах певної держави. До ознак корпоративних актів відносять їх внутрішній, внутрішньогосподарський характер, тобто вони врегульовують питання у межах певної корпорації у широкому сенсі. Оскільки це можуть бути саморегулівні організації, то їхня дія поширюється на їхніх членів, а також асоційованих членів (на основі договору).

Стаття 7 Господарського кодексу України (далі - ГК України) передбачає положення щодо нормативно-правового регулювання господарської діяльності, до якого віднесено Конституцію України, ГК України, закони, нормативно-правові акти Президента України та Кабінету Міністрів України, нормативно-правовими актами інших органів державної влади та органів місцевого самоврядування, а також інші нормативні акти. Однак про нормативні акти саморегулювання не йдеться взагалі, не кажучи вже про корпоративні акти. Звичайно, можна вказати, що у статті передбачені «інші нормативні акти», однак виходячи з розуміння «духу» цієї статті, 
можна розуміти під цим терміном акти, які виходять від органів державної влади та місцевого самоврядування (публічних органів), але аж ніяк від приватних суб'єктів. Тому враховуючи місце актів саморегулювання, яке вони стали займати у сучасному українському суспільстві, слід доповнити статтю 7 ГК України частиною 2 такого змісту: «Відносини у сфері господарювання регулюються нормативними актами суб'єктів господарювання, саморегулівних організацій. До таких актів можуть бути віднесені: принципи корпоративного управління, етичні кодекси, регламенти, добровільні угоди, стандарти, кодекси усталеної практики. Перелік не є вичерпним та не залежить від назви нормативного акта. Суб'єкти господарювання, саморегулівні організації можуть приймати нормативні акти у межах, визначених законодавством України та міжнародними договорами». Зрозуміло, що частина визначених видів нормативних актів передбачена галузевим законодавством, однак закріплення цього базового положення у Господарському кодексі України надасть ваги процесам саморегулювання, які відбуваються в Україні.

\section{Висновки}

Отже, корпоративний акт як засіб саморегулювання у господарському праві - це документ, незалежно від назви, форми, структури та змісту, який самостійно приймається, ухвалюється певною корпоративною спільнотою, організацією (господарським товариством, господарським об'єднанням, саморегулівною організацією) з питань упорядкування певної сфери, галузі, виду господарської діяльності або внутрішньогосподарської діяльності у межах чинного законодавства та міжнародних договорів. Така дефініція допомагає конкретизувати суб'єктний склад та визначати видові особливості корпоративного акта.

\section{Список використаних джерел:}

1. Peters, Anne and Pagotto, Isabella, Soft Law as a New Mode of Governance: A Legal Perspective (February 28, 2006). NEWGOV: New Modes of Governance. URL: https://ssrn.com/ abstract=1668531 or http://dx.doi.org/10.2139/ ssrn.1668531 (дата звернення: 20.05.2019).
2. Бакалінська О.О. Правове забезпечення добросовісної конкуренції в Україні: проблеми теорії і практики : дис.... докт. юрид. наук: 12.00.04. / Київ: Науково-дослідний інститут приватного права і підприємництва імені Ф. Г. Бурчака. $510 \mathrm{c}$.

3. Гончаренко О. Види саморегулювання господарської діяльності. Підприємництво, господар ство і право. 2016. № 11. С. 68-72.

4. Антошкіна В.К. Роль правочину, корпоративних актів у процесі саморегуляції цивільноправових відносин. Часопис Київського університету права. 2015. № 4. С. 156-161.

5. Шуба Б.В. Корпоративне право і законодавство: поняття і систематизація. Свропейські перспективи. 2013. № 5. С. 137-140

6. Тичкова О.Ю. Локальні корпоративні норми у цивільно-правовому регулюванні : автореф. дис... канд. юрид. наук: 12.00.03. Харків, 2009. 20 с.

7. Звонков Є.Є. Корпоративні акти: природа, сутність та значення. Часопис Київського університету права. 2014. № 3. С. 307-309.

8. Пальчук П. М. Корпоративне право : навчальний посібник. Київ : КНТЕУ, 2015. 315 с.

9. Томашевська М.О. Корпоративні акти в системі джерел права України. Держава і права. Юри дичні і політичні науки. 2002. Вип. 18. С. 47-50.

10. Соляр С. Корпоративна нормотворчість інститутів громадянського суспільства. Вісник Академії правових наук України. 2010 . № 4(63) C. 80-89.

11. Тичкова О.Ю. Локальні корпоративні норми у цивільно-правовому регулюванні : дис... канд. юрид. наук: 12.00.03. Харків, 2009. 227 с.

12. Форманюк В. В. Реалізація локальних нормативно-правових актів. Актуальні проблеми держави і права. 2012. Вип. 68. С. 184-189.

13. Руденко М.П. Правове регулювання внутрішньогосподарських відносин : дис.... канд. юрид. наук: 12.00.04. Харків, 2017.

14. Кучеренко I.M. Організаційно-правові форми юридичних осіб приватного права. Київ ДП «Юридичне видавництво «Аста», 2004. 248 с.

15. Словник української мови: в 11 томах. Том 4, 1973. С. 542

16. Ісаков М.Г., Паркулаб В.Г. Тенеденції і перспективи становлення корпоративної нормотворчості: зарубіжний досвід. Науковий вісник публічного та приватного права. 2017. Випуск 5. Т. 1. C. $133-138$

17. Кириленко I.С. Локальна нормотворчість в системі юридичного процесу. Науковий вісник Херсонського державного університету. Серія «Юридичні науки». 2013. Випуск 3. Том 1. С. 25-28.

The features of corporate act as a tools of self-regulation of economic activity are investigated. A corporate act defines, formalizes "rules of the game" for participants and members of the corporate community (corporation), aimed at detailing the ordering of relationships. It has been established that certain types of corporate acts are elements in the system of "soft law", which are created and formed by economic entities and their associations (transnational companies, self-regulatory organizations and separate economic entities).It is sett hat separate types of corporate acts are elements in thesystem "soft right", that is creat$e d$ and formed by thesubjects of menage and their associations (by transnational companies, self-regulato- 
ry organizations and separate subjects of economic activity). To means of «soft» law take public documents, acts of the general co-regulation and private self-regulation, which carry mostly recommendation character or become obligatory as a result of agreements between sides or one-sided will. Certainly, that corporate act as a mean of self-regulation of economic activity is a document, regardless of the name, form, structure and maintenance which is independently accepted, accepted a certain corporate association, organization (by economic society, economic association, self-regulatory organizations), on questions arrangement of certain sphere, industry, type of economic activity, within the limits of current legislation and international agreements. Corporate acts are more flexible in compared to the legislative norms, have an excellent mechanism of acceptance, own the sign of normativeness. Corporations can accept individual acts, which do not contain norms, but are the result of functioning of their organs. Corporate acts can be alternative government normative control (in the case of permission) or to be the additional adjusting to basic. Corporate acts can have transfrontal, transnational character, going out outside the certain state. It follows to complement the article 7 of Economic Code of Ukraine part 2 such maintenance: «Relations in the field of menage are regulated the normative acts of subjects of economic activity, self-regulatory organizations. To such acts can be taken: principles of corporate management, ethics codes, regulations, voluntarily agreements, standards, codes of a withstand practice. The subjects of economic activity, self-regulatory organizations, can accept normative acts within the limits of certain the legislation of Ukraine and international agreements».

Key words: self-regulation, self-regulation of economic activity, self-regulatory organizations, corporate community, corporate act, self-regulation tool, soft law. 